\title{
English Get-Passives: Reassessing the Frequencies across Genres
}

\author{
Supakorn Phoocharoensil \\ supakorn.p@litu.tu.ac.th \\ Language Institute of Thammasat University, Thailand
}

\begin{abstract}
This study investigates the get-passive in American English, with emphasis on its distribution in different text types and its semantic features characterized by co-occurring verbs. The data was drawn from the Corpus of Contemporary American English (COCA), i.e. the latest version with eight different genres. The findings indicate that the get-passive is a linguistic feature of informal English due to its highest frequency in spoken genres, e.g. TV and movie subtitles, and blogs. Furthermore, common verbs constituting the get-passive were explored and their meanings in context were analyzed. In agreement with previous studies, the semantic analysis of get-passives revealed a higher proportion of verbs expressing adversity, followed by those with positive and neutral meanings, respectively. The existence of non-adversative get-passive predicts a decline in the adversative type.
\end{abstract}

Keywords: get-passive; text type; common verb; COCA; adversative and non-adversative meaning

\section{INTRODUCTION}

A clear understanding of English grammar increases learners' accuracy in second language (L2) English comprehension and production. As one of the most common points of grammar, the passive construction presents challenges for learners of English as a foreign language (EFL). Learners from different L1 backgrounds are often confronted with the complicated usage of passives in English (Loan, 2019). Those whose L1 lacks the passive voice are often seen struggling with the acquisition of L2 English passives (Cowan, 2008). Even for learners whose L1 contains some limited form of the passives often encounter difficulties. To illustrate, L1-Thai speakers, whose L1 allows passives primarily with a negative sense of meaning, are found to commit errors in their interlanguage English passive constructions (Simargool, 2008).

As an alternative to 'the be-passive', i.e. the passive construction made up of be and past participle, 'the get-passive', i.e. the structure comprising get and past participle, is natural in spoken English (Leech, Hundt, Mair \& Smith, 2009). Several corpus-based studies place an emphasis on the use of get-passives in major varieties of English (e.g. Carter \& McCarthy, 1999; Mair, 2006), while others make a comparison between Inner-Circle Englishes, such as British English, and Outer-Circle Englishes, such as Philippine English (e.g. Alonsagay \& Nolasco, 2010), or Expanding-Circle Englishes, such as Swedish English (e.g. Fredriksson, 2016) and Chinese English (e.g. McEnery \& Xiao, 2010).

The focus of this study is on the occurrence of get-passives in various text types representing American English, as shown in the Corpus of Contemporary American English (COCA) and common verbs, from which the get-passive structures are constructed.

The following section reviews the major concepts and past studies related to English get-passives. 


\section{LITERATURE REVIEW}

\section{THE ENGLISH GET-PASSIVE}

An action expressed by a clause can generally be viewed in two possible ways: active voice, as in (1), and passive voice, as in (2), both of which are identical in meaning. In (1), the subject the dog receives emphasis as it is the doer or 'the agent' of the verb saw, and the object the cat is 'the patient', i.e. the person or thing that the action was done to (Chan \& Maglio, 2020). In (2), by contrast, the patient the cat becomes the topic or the subject of the corresponding passive sentence, whereas the agent the dog appears in the prepositional phrase by the dog. This byphrase can sometimes be omissible if "the doer of the verb is not important or not known or if we do not want to say who the doer is" (Carter, McCarthy, Mark \& O'Keeffe, 2011, p. 363).

(1) The dog saw the cat.

(2) The cat was seen by the dog.

(Crystal, 2004, p. 96)

(Crystal, 2004, p. 96)

Alternatively, the be-passives can also be replaced by get-passives. For instance, (3) and (4) are semantically equal. It is worth noting that the get-passive usually occurs in informal speaking. The use of get-passive emphasizes the nature of the action itself or the person involved in the action (Carter, McCarthy, Mark \& O'Keeffe, 2011).

(3) The trees in the garden were damaged in the wind.

(Carter, McCarthy, Mark \& O’Keeffe, 2011, p. 222).

(4) The trees in the garden got damaged in the wind.

(Carter, McCarthy, Mark \& O’Keeffe, 2011, p. 222).

SEMANTIC FEATURES OF GET-PASSIVES

(5) He feels his paintings are always getting criticised.

(Carter, McCarthy, Mark \& O’Keeffe, 2011, p. 222).

(6) Our car got stolen last night.

(Carter, McCarthy, Mark \& O’Keeffe, 2011, p. 222).

The get-passive usually expresses meanings that are negative, undesirable, or adversative, as shown in the verbs criticised in (5) and stolen in (6). This structure often reflects an unfavorable attitude toward the action (Biber, Johansson, Leech, Conrad, \& Finegan, 1999). Many subsequent studies provide support for this finding. According to Francis, Hunston \& Manning (1996), the get-passive is indicative of an unpleasant situation and often conveys the speaker's negative attitude toward that situation. In a similar vein, a corpus-based study by Stubbs (2001) also corroborates such a notion in that the motivating factor in the communicative aspect of the get-passive is its negative connotation. Nevertheless, Carter \& McCarthy (1999) revealed that not only is the get-passive often associated with adversative meanings but it also expresses neutral senses, as in get involved, or positive senses, as in get paid. 


\section{SYNTACTIC FEATURES OF GET-PASSIVES}

Some aspects of the syntactic features of get-passives are as follows. First, unlike be-passives, get-passives are normally used without an expressed agent, thereby not preceding a by-phrase (Crystal, 2004). This agentless passive construction emphasizes the patient rather than an agent, and it is far more likely to occur with the patient being a recipient of a negative action (Mair, 2006). By way of illustration, the be-passive with a by-phrase in (7) is more common than the corresponding get-passive with a by-phrase in (8).

(7) I was hurt by the car.

(Crystal, 2004, p. 97)

(8) I got hurt by the car.

(Crystal, 2004, p. 96)

Another aspect lies in the type of verb co-occurring with the get-passive. While the bepassive can be used with both dynamic and stative verbs, the get-passive requires only dynamic verbs, as in get stuck, get killed, get bitten, etc.

In addition, the get-passive can also be used in some idiomatic expressions, such as get married, get washed, get shaved, get (un)dressed, get changed, get engaged, get divorced, get started, get lost (Eastwood, 2005, p. 127).

\section{PAST STUDIES ON THE GET-PASSIVE}

Sawasaki (2000) investigated English native speakers' perceptions of get-passives, looking at how the get-passive configuration and the animacy of the subject with and without contextual information play a role to constitute the adversative implication. The results indicated that a significant increase of native speakers' perceived adversity was clearly seen only when getpassives and human-subject factors were combined. It is, however, important to note that the actual ratio of adversity for get-passives was only 0.3704 , which is not remarkably high, whereas the ratio for neutrality was considerably higher (0.5148).

A corpus-based study that analyzed English get-passives was conducted by Mair (2006). The findings revealed a steady rise in the use of get-passives in both British English, as can be seen in Lancaster-Oslo/Bergen Corpus (LOB), Freiburg LOB Corpus (FLOB), and Freiburg Brown Corpus (FROWN), and American English, as demonstrated in the Time Corpus. A sudden increase in the get-passives could be seen from the 1990s onwards. Like other previous studies, Mair found that get-passives predominantly involve verbs with negative meanings, e.g. get caught, get busted, get hurt, get killed, get sacked. Although some verbs might sound positive, e.g. kiss, the context in which they appear are often adversative in meaning. In a specific example from the corpus data, a woman got kissed by a nasty man; this shows the particular kiss was something unpleasant.

Mair, in line with Carter \& McCarthy (1999), discovered that the negative sense of getpassives is neutralized when accompanied by verbs with a neutral or positive meaning. To be more precise, out of the top-20 verbs used in the get-passive in the BNC (British National Corpus) and COCA, only 12 verbs express negative senses, namely caught, smashed, hit, damaged, killed, hurt, shot, beaten, stopped, sacked, accused, and destroyed. Four of these verbs are positive in meaning, namely paid, promoted, invited, and served. The verbs played and written are semantically neutral, while the meanings of eaten and fucked are uncertain. Consequently, constraints on the use of get-passive with positive words have weakened.

In search of the get-passive and the be-passive in the Brown family of corpora, Leech, Hundt, Mair \& Smith (2009) reported on approximately 400 occurrences of the be-passive than 
the get-passive in written and formal spoken English. Furthermore, the frequency of getpassives doubled from the 1960s to 1990s in American English. More specifically, occurrences of get-passives were found most frequently in fiction, with press and general prose occupying the middle ground, and academic prose containing the fewest. Even in colloquial English, the get-passive is largely restricted to informal face-to-face conversations. Due to the fact that there was no sharp increase in get-passives in British English in comparison with American English, it can be concluded that American English was in the lead of an ongoing change. With regard to semantics of the get-passive, the slight rise from the 1960s to the 1990s has still not exhibited a marked shift towards a more neutral meaning. It was further observed that " $[\mathrm{t}]$ he majority of get-passives are still adversative. On the contrary, the relative frequency of adversative getpassives has even increased slightly." (p. 156). They also cited some corpus examples to illustrate the typical adversative meaning of the get-passive, as in (9)-(10).

(9) Did they know how wealth from over-large estates gets misused?

(Leech, Hundt, Mair \& Smith, 2009, p. 157)

(10) We've been through too much together to get killed now.

(Leech, Hundt, Mair \& Smith, 2009, p. 157)

Even though they also found some get-passives with non-adversative, neutral semantics, as in (11), as well as some with positive connotations, as in (12), "these are not beginning to make a major contribution to the neutralization of the semantics of the getpassive.” (p. 157).

(11) ... if people are to learn to live together and get trained to do things well,...

(Leech, Hundt, Mair \& Smith, 2009, p. 157)

(12) ...those who deserve rewards get rewarded appropriately.

(Leech, Hundt, Mair \& Smith, 2009, p. 157)

Leech, Hundt, Mair \& Smith concluded that the non-neutral semantics of the getpassive is a strong reason why it is unlikely for the be-passive to be replaced by the get-passive in the near future. In other words, the get-passive is a very infrequent alternative to the bepassive in written and formal spoken English. Such a finding is consistent with Mair \& Leech's (2006) study on major changes in English syntax, which showed that although an exploration of get-passives in four different corpora confirmed a significant increase in this particular passive structure in American and British English, the rise was so infinitesimally small that get-passives cannot compensate for the decline in be-passives.

Wanner (2013) revisited the adversity effect expressed by get-passives, based on an analysis of the FROWN corpus of written American English. Data from the FROWN corpus do not suggest that the get-passive is inherently semantically adversative. That is, two-thirds of get-passives found in the corpus are negative in meaning, such as get caught, get overrun, get overlooked, get squeezed, get zapped, get blown into pieces, get pressured into, get killed, get fired, get struck, etc. The remaining get-passives are neutral, as exemplified in (13)-(14), in which get passed and get elected do not have any negative connotation. Wanner argued that the high frequency of adversative get-passives is "a by-product of the register in which the getpassive is used" (p. 58). Put simply, it is "the informal, colloquial character of the get-passive, rather than the construction itself, which favors colloquial expressions of someone or something being strongly affected" (p. 53). 
(13) Much of the savings get passed along to consumers in the form of lower prices.

(14) An Rev Tillis will get elected.

(Wanner, 2013, p. 52)

(Wanner, 2013, p. 52)

Villalibre (2015) examined the get-passive in the spoken part of a series of corpora of the International Corpus of English (ICE), including British English, Indian English, Hong Kong English, and Singapore English. In line with Leech, Hundt, Mair \& Smith (2009), Mair (2006), and Wanner (2013), the study revealed that the get-passives in the corpora are mixed between adversative and non-adversative types. It is noteworthy that in three of the subcorpora, namely British, Hong Kong and Singapore English, the neutral implications are almost as common as the adversative connotations. The semantic adversity of get-passives appears to be strongly associated with [+human] subjects. A drastic increase in inanimate subjects in American English, together with a slight inanimate-subject rise in British English, which correlates with a drop in [+human] subjects in the current English may explain a change in meaning of get-passives, "shifting from primarily adversative semantics to more neutral contexts" (p. 22).

Some diachronic studies on get-passives revealed increasing frequencies of this passive construction in American English. Schwarz (2017) reported on far higher number of getpassives in newspapers from the second half of the 20th century. The rise in get-passives use is attributed to colloquialization, which means features of spoken language are increasingly accepted in written language. A more recent study by Schwarz (2019) looked at get-passives in different genres and time periods based on the data from the Corpus of Historical American English (COHA). It was clear that get-passives increased dramatically between the 1870 s and the 1990s and this passive structure continues to grammaticalize over the period. In other words, the verb get as the main component of get-passives undergoes a shift from a more lexical function to a more grammatical one as there seem to be more contexts in which the use of getpassives is allowed. Furthermore, according to the data from COHA, Fiction and Popular Magazines, i.e. the text types representing informal written language, are the two genres in which the highest frequencies get-passives were identified.

As can be seen in the reviewed studies, several attempts have been made to either analyze the English get-passive in terms of semantics and syntax or to compare and contrast it with the $b e$-passive in different contexts. Although some studies devoted to an investigation of the get-passive in American English are based on a large corpus like COCA (e.g. Mair, 2006), those studies cover only the five conventional genres presented in COCA, i.e. Fiction, Spoken, Academic Journals, Newspapers, and Popular Magazines. This study aims to extend its scope to three new text types added to COCA in March 2020, i.e. TV and Movie Subtitles, Blogs, and Webpages, with emphasis on the verbs which frequently appear in the get-passive. The main findings will respond to two major research questions below:

1. What are the occurrences of get-passives across text types in American English?

2. What are the common verbs constituting get-passives in American English?

\section{METHOD}

\section{DATA COLLECTION PROCEDURE}

The current study is based on the data from a corpus of more than one billion words of text, representing American English, i.e. the Corpus of Contemporary American English or COCA (Davies, 2020). COCA is one of the most widely-known corpora used as a reference for both 
TESOL practitioners and language researchers (Crawford \& Csomay, 2016). At present, COCA contains texts of eight different genres, namely five traditional genres, i.e. Spoken, Fiction, Popular Magazines, Newspapers, and Academic Texts, and three new genres, i.e. TV and Movie Subtitles, Blogs, and Webpages.

It is useful to rely on data from COCA for the following reasons (Schmitt, 2010). First, COCA is considered an American-English corpus which is presumably larger than any other available American English corpus. It is comparable to the British National Corpus (BNC), which contains 100 million words of text from an extensive range of genres, such as spoken language, fiction, magazine, newspaper, and academic texts. Second, COCA is regarded as a genre-balanced corpus with data gathered from texts equally divided among various genres. This accounts for why COCA is one of the largest and best-developed corpora of current English. Finally, COCA is a monitor corpus, which means that it is constantly expanding as additional texts are added on a yearly basis.

With its primary goal to provide answers for the two aforementioned research questions, the present study focuses on the frequency and distribution of get-passives in the eight different text types. Furthermore, the top-30 verbs frequently constituting the get-passive were explored. To obtain all possible verb forms of the lemma GET, i.e. get, gets, got, and getting, followed by a verb in the past participle form, [get]_vvn was entered into the search box. To follow Mair's (2006) analytical framework, formulaic get-passives, i.e. those used in some idiomatic expressions, such as get started, get married, get changed, get laid, get lost, get involved or get rid (of), were excluded from the study. Moreover, any verbs that are potential components of phrasal verbs, e.g. picked (e.g. picked up, picked on), called (e.g. called off, called on), and taken (e.g. taken over, taken up), were considered beyond the scope of this study. Next, the common verbs as a constituent of get-passives were classified as adversative, positive, and neutral, in order to identify their meanings. When the meaning of get-passives is neutral or positive, the animacy of the subject was also taken into consideration. It has also been hypothesized that there is a strong relationship between inanimate subjects and non-adversative get-passives.

\section{RESULTS AND DISCUSSION}

As seen in Table 1, get-passives occur with the highest frequency in TV and Movie subtitles (50,926 tokens). The frequency of this construction in Blogs (34,353 tokens) and Spoken $(33,009$ tokens) are quite close. Such results lend support to past studies in that get-passives are characteristic of colloquial English, such as face-to-face informal conversations (e.g. Mair, 2006; Leech, Hundt, Mair \& Smith, 2009; Wanner, 2013). While Mair (2006) found that getpassives are most common in the spoken subcorpus of COCA due to the existing corpus data available at that time, the present study gives a clearer picture of the distribution of this passive structure in American English. The high frequency of get-passives in TV and Movie subtitles, followed by Blogs and Spoken respectively, largely supports Mair (2006) in that all these genres characterize informal English. Evidently the language reflected in this genre in COCA is based on the American component of TV and Movies corpora and is claimed to be as informal as or sometimes even more informal than actual spoken data (Davies, 2020). The current trend in the occurrences of get-passives still confirms its high degree of informality in English. Conversely, the frequency of get-passives appear to be the lowest in Academic Texts, which also reaffirms that this particular passive structure is informal, and thus uncommon in formal, academic text types. 
TABLE 1. Distribution of Get-Passives across Genres

\begin{tabular}{ccc}
\hline Genre & Frequency & Per Million \\
\hline TV and Movie subtitles & 50,926 & 397.63 \\
Blogs & 34,353 & 267.10 \\
Spoken & 33,009 & 261.69 \\
Web pages & 26,869 & 216.24 \\
Fiction & 21,756 & 183.87 \\
Popular magazines & 19,638 & 155.74 \\
Newspapers & 17,673 & 145.17 \\
Academic texts & 3,867 & 32.28 \\
TOTAL & 208,091 & \\
\hline
\end{tabular}

Apart from the distribution of get-passives across different eight genres, verbs that frequently form the passive construction were also observed, as well as the meaning, i.e. adversative or non-adversative, expressed by get-passives.

Table 2 lists the most common verbs found in the construction of get-passives in COCA. The findings show that get caught and get paid rank first and second in the frequency list, which is consistent with Mair (2006), who examined only the subcorpus Spoken of COCA. Aside from the two verbs discovered to have the highest frequency, there are other common verbs that both Mair (2006) and this study found in COCA, namely hit, promoted killed, hurt, eaten, and invited. Since the present study deals with an extensive amount of data drawn from the eight genres, as opposed to Mair's more limited data obtained from only one subcorpus, i.e. Spoken, not all possible verbs as a constituent of get-passives are included in Table 2. Only the top 30 high-frequency verbs in all the genres are displayed here, while others with lower frequency or possibly restricted to Spoken, as reported by Mair (2006), are left unlisted, namely smashed, damaged, fucked, shot, beaten, stopped, sacked, accused, served, written, played, and destroyed. In contrast, the current study revealed additional verbs not found in Mair's, e.g. elected, arrested, kicked, sent, passed, notified, published, raped etc.

TABLE 2. Frequent Verbs Used in Get-Passives in COCA

\begin{tabular}{ccc}
\hline Rank & Verb & Frequency \\
\hline 1 & caught & 10,803 \\
2 & paid & 8,988 \\
3 & hit & 4,597 \\
4 & fired & 2,943 \\
5 & elected & 2,939 \\
6 & arrested & 2,153 \\
7 & killed & 1,557 \\
8 & kicked & 1,546 \\
9 & thrown & 1,392 \\
10 & knocked & 1,269 \\
11 & burned & 970 \\
12 & sucked & 941 \\
13 & sent & 921 \\
14 & passed & 809 \\
15 & hooked & 769 \\
16 & asked & 631 \\
17 & notified & 630 \\
18 & left & 616 \\
19 & invited & 565 \\
20 & hurt & 556 \\
21 & promoted & 540 \\
22 & locked & 509 \\
23 & tested & 495 \\
\hline
\end{tabular}




\begin{tabular}{ccc}
\hline 24 & noticed & 463 \\
25 & trapped & 462 \\
26 & published & 355 \\
27 & eaten & 332 \\
28 & reelected & 281 \\
29 & bitten & 252 \\
30 & raped & 246 \\
TOTAL & & $\mathbf{4 9 , 5 3 0}$ \\
\hline
\end{tabular}

Table 3 lists common verbs as a component of get-passives whose meanings are adversative. In this table, 17 out of 30 verbs, equal to $63.76 \%$ (31,581 tokens), refer to adversative contexts. The amount of the get-passives in all the genres in COCA, i.e. approximately two-thirds, is consistent with the proportion reported in Wanner's (2013) study of American English represented by the FROWN corpus. This accords with Biber, Johansson, Leech, Conrad, \& Finegan (1999), who concluded that the get-passive typically co-occurs with verbs that have "negative connotations, conveying that the action of the verb is difficult or to the disadvantage of the subject" (p. 481). The findings also provide support for Villalibre (2015) in that more get-passives in the L1-English (i.e. British) and ESL (Hong Kong and Singapore) corpora convey adversative consequences for the subject. Some corpus examples of adversative verbs forming the get-passive are provided in (15)-(19).

(15) For example if you get caught by private security with drugs at a lot of places they'll just throw...

(16) ...I got pulled over and charged for driving without a license on a scooter. I got arrested and everything...

(17) I haven't ever worked there but my gf's friend just got fired for failure to take mandated breaks.

(18) We Know It is a LOL eBook about a group of high school seniors who get locked in the basement during the biggest party of the year,...

(19) The bad news is that if she does get raped, her chances of getting killed after the rape go up dramatically.

TABLE 3. Verbs with Adversative Meanings Used in Get-Passives

\begin{tabular}{ccc}
\hline Rank & Verb & Frequency \\
\hline 1 & caught & 10,803 \\
2 & hit & 4,597 \\
3 & fired & 2,943 \\
4 & arrested & 2,153 \\
5 & killed & 1,557 \\
6 & kicked & 1,546 \\
7 & thrown & 1,392 \\
8 & knocked & 1,269 \\
9 & burned & 970 \\
10 & sucked & 941 \\
11 & hooked & 769 \\
12 & left & 616 \\
13 & hurt & 556 \\
14 & locked & 509 \\
15 & trapped & 462 \\
16 & bitten & 252 \\
17 & raped & 246 \\
TOTAL & & $\mathbf{3 1 , 5 8 1}$ \\
\hline
\end{tabular}


The COCA data indicates that the subjects of the get-passives are usually human or animate, who are involved in adversative situations, i.e. "a state of affairs that is signaled contextually by the conversational participants as unfortunate, undesirable, or at least problematic" (Carter \& McCarthy 1999, p. 49). However, get-passives with non-human subjects in adversative contexts are occasionally seen in the corpus, as in (20)-(21). In fact, the affected entity of the get-passive is not always the inanimate subject but rather the person who possesses it (Collins, 1996). In (20), the get-passive is considered to be adversative because of the adverse effect of the 'burning' action upon the speaker. Likewise, got sucked in (21) affects the speaker as the owner of the phone, as opposed to the device itself. It seems that the type of verb determines its subject in such a way that some verbs, e.g. get arrested, get fired, get raped, require only human subjects, while some others have more flexibility, allowing for non-human or inanimate subjects as well, e.g. get burned, get sucked, get thrown etc.

(20) First, it didn't come out the way I wanted. The sauce got burned. It's a pan-seared striped bass with a chocolate miso sauce.

(21) My GPS card - it must have stuck to Sputnik when my phone got sucked into it.

In addition to the adversity expressed by the get-passive as shown in COCA, nonadversative verbs also appear, accounting for approximately $36.29 \%$ (17,979 tokens). The onethird proportion of non-adversative verbs found in get-passives in COCA is similar to Wanner's (2013) findings from the FROWN corpus of American English. That around 2 in 3 of getpassives have negative connotations, while the remaining get-passives are non-adversative may indicate that "adversativeness is not built into the construction" (p. 52).

Non-adversative verbs are divided into two subcategories: beneficial and neutral verbs. The 7 verbs whose meanings are positive or 'beneficial' (Villalibre, 2015) are paid, elected, passed, invited, promoted, noticed, and reelected, all of which account for $29.45 \%(14,585$ tokens) and listed in the frequency order in Table 4. The verbs are also reported in other American-English corpora, e.g. elected and passed in FLOWN (Wanner, 2013). Many of these verbs also exist in get-passives in other Inner Circle varieties of English, such as British English, e.g. paid (Carter \& McCarthy, 1999; Leech, Hundt, Mair \& Smith, 2009) and elected (Gustafsson, 2014), and the Outer Circle varieties of English, such as Hong Kong English, e.g. paid, passed, reelected (Villalibre, 2015), Singapore English, e.g. elected, paid, passed (Villalibre, 2015), and Indian English, e.g. elected, promoted (Villalibre, 2015).

TABLE 4. Verbs with Positive Meanings Used in Get-Passives

\begin{tabular}{ccc}
\hline Rank & Verb & Frequency \\
\hline 1 & paid & 8,988 \\
2 & elected & 2,939 \\
3 & passed & 809 \\
4 & invited & 565 \\
5 & promoted & 540 \\
6 & noticed & 463 \\
7 & reelected & 281 \\
TOTAL & & $\mathbf{1 4 , 5 8 5}$ \\
\hline
\end{tabular}

Some examples of beneficial get-passives from COCA are given in (22)-(25).

(22) They got paid two to five times their government salaries and produced half the product.

(23) ... whoever they voted for is just as President as someone who got elected unanimously by every American voting.... 
(24) At the end of the day either progressive laws get passed or they don't and either wingnut rethug laws get passed or they do...

(25) but Martin Sheen was made of too much awesome, and got promoted to a member of the main cast.

The verb noticed appears to be interesting in the get-passive construction. By itself, the verb seems to be neutral in meaning, but when it is combined with get in this passive structure, the composite meaning becomes positive, as in (26)-(27), as they mean 'to get attention or become easier to be seen'. It is clear from the data that the occurrences of get-passives involve not only adversity but also benefit, as noted by Huddleston and Pullum (2002).

(26) There are always comedians who will work hard and get noticed by agents and managers and record labels.

(27) While tens of thousands of artists are self-releasing their music, their ability to get noticed in a meaningful way is stifled by the sheer volume of music.

Common neutral verbs in the get-passives shown in COCA, accounting for approximately $6.79 \%$ (3,364 tokens) are asked, sent, notified, tested, published, and eaten, as presented in Table 5. Some of the verbs also occur in other corpora representing different Englishes, e.g. eaten in British English, i.e. British National Corpus (Mair, 2006), and sent and published in Hong Kong English (Villalibre, 2015). Some instances of neutral verbs in the getpassives in COCA are presented in (28)-(31).

(28) The details I get asked about the most on this costume are the patches.

(29) Sign in to get notified via email when new comments are made.

(30) You can get tested for health problems that run in families before getting pregnant...

(31) And the point was made that you're more likely to get published as a legal scholar if you surround yourself with other legal scholars...

TABLE 5. Verbs with Neutral Meanings Used in Get-Passives

\begin{tabular}{ccc}
\hline Rank & Verb & Frequency \\
\hline 1 & asked & 631 \\
2 & sent & 921 \\
3 & notified & 630 \\
4 & tested & 495 \\
5 & published & 355 \\
6 & eaten & 332 \\
TOTAL & & $\mathbf{3 , 3 6 4}$ \\
\hline
\end{tabular}

The approximately one-third of non-adversative get-passives occurring in COCA provide some evidence that get-passives are not inherently semantically negative. In reality, the passive construction itself has nothing to do with adversity, but the negative senses frequently associated with get-passives reflect speakers' attitudes (Sawasaki, 2000; Villalibre, 2015). Due to the fact that the get-passive is considered a common feature of spoken English, its colloquial character appears to co-select expressions or environments in which persons or things are strongly affected (Wanner, 2013). This is why the subjects of adversative getpassives are often human or animate. Although the subjects of get-passives can sometimes be things, the effect of the adversative verbs is actually on the persons owning those things rather than the things themselves (Collins, 1996).

Regarding non-adversative get-passives found in this study, most of the subjects are still human or animate. Even though it was hypothesized that there might be a correlation 
between neutral get-passives and inanimate subjects, this hypothesis was not borne out by the available data as most of the get-passive occurrences seem to have human subjects. However, the subjects are possibly pre-determined by the verbs since some verbs primarily require nonhuman subjects, e.g. eaten, while others allow both human and non-human subjects, e.g. passed and sent. The high frequency of human subjects may be related to the genres in which getpassives appear. That is, as get-passives in COCA occur with the highest frequency in TV and Movie subtitles, Blogs, and Spoken, all of which represent spoken, informal English, it is likely for human subjects to be used in get-passives, whereas non-human subjects are common in more formal contexts (Villalibre, 2015; Wanner, 2013).

\section{CONCLUSION}

The present study centers around the occurrences of get-passives in terms of text-type distribution and typical verbs in American English represented by COCA. The results indicate that get-passives are very common in formal, colloquial English with the highest frequency occurring in TV and movie subtitles, blogs, and spoken language, respectively, whereas the structure occurs with the lowest frequency in academic texts, i.e. a genre with a very high degree of formality. Such a clear distribution of get-passives across different text types, with their remarkably high rate of use in informal genres, confirms previous studies' findings as to the association between the get-passive and conversational English (e.g. Leech, Hundt, Mair \& Smith, 2009; Mair, 2006; Wanner, 2013).

Apart from the text types, this study also concentrates on verbs commonly used in constructing get-passives. These common verbs were classified according to the senses of meaning they convey. An analysis of verb meanings demonstrates that, as suggested by a number of studies (e.g. Biber, Johansson, Leech, Conrad, \& Finegan, 1999; Leech, Hundt, Mair \& Smith, 2009; Mair, 2006), get-passives are mainly associated with adversative meanings, as can be seen in the verbs with negative connotations like get arrested, get burned, get fired, get killed, get kicked, get bitten, get raped, etc. The proportion of adversative get-passives in COCA, i.e. two-thirds, is also consistent with that reported in Wanner's (2013) study. More interestingly, the remaining get-passives are non-adversative, which means they are semantically positive (e.g. get paid and get promoted) or neutral (e.g. get notified and get eaten). The increasing use of non-adversative get-passives provides support for other studies that discovered non-adversative meanings of this passive structure in British English (e.g. Leech, Hundt, Mair \& Smith, 2009), as well as Outer Circle Englishes, e.g. Hong Kong and Singapore English (Villalibre, 2015). The gradual rise in neutral and positive get-passives may correlate with the decrease in the adversity expressed by get-passives. It is anticipated that the adversative meaning of get-passives is in a downward trend (Villalibre, 2015).

The current study is not without limitations. The first concerns the types of verb being analyzed in this study. Since the study aims to investigate only single-word verbs as a constituent of get-passives, two-word or phrasal verbs were not included. Future research may take phrasal verbs into consideration so as to obtain a clearer picture of more verbs as a cooccurring element of get-passives. The second limitation pertains to the source of data. The present study drew data from COCA, which represents American English, as a standard variety of English. However, second language researchers might be interested in looking at getpassives in the interlanguage of EFL or ESL learners and conduct a comparative study between get-passives in learner language and those in native-speaker English. Ultimately, this study did not compare between get-passive and be-passives. Although a comparison between both types of passive constructions is not new, examining them in a vast corpus like COCA may yield additional results not evidenced in prior studies. 


\section{REFERENCES}

Alonsagay, I. \& Nolasco, J. (2010). Adversativity and the Get-passive in Philippine and British English: A corpus-based contrastive study. Philippine Journal of Linguistics. 41, 1-13.

Biber, D., Johansson, S., Leech, G., Conrad, S. \& Finegan, E. (1999). Longman Grammar of Spoken and Written English. London: Longman.

Carter, R. \& McCarthy, M. (1999). The English Get-passive in Spoken Discourse: Description and Implications for an Interpersonal Grammar. English Language and Linguistics. 3(1), 41-58.

Carter, R., McCarthy, M., Mark, G, \& O’Keeffe, A. (2011). English Grammar Today. An A-Z of Spoken and Written Grammar. Cambridge: Cambridge University Press.

Chan, E. Y. \& Maglio, S. (2020). The Voice of Cognition: Active and Passive Voice Influence Distance and Construal. Personality and Social Psychology Bulletin. 46(4), 547-558.

Collins, P. (1996). Get-passives in English. World Englishes. 15, 43-56.

Cowan, R. (2008). The Teacher's Grammar of English. Cambridge: Cambridge University Press.

Crawford, W. J. \& Csomay, E. (2016). Doing Corpus Linguistics. London: Routledge.

Crystal, D. (2004). Rediscover Grammar. Essex: Pearson Education

Davies, M. (2020). Corpus of Contemporary American English.

Eastwood, J. (2005). Oxford Learner's Grammar. Oxford: Oxford University Press.

Francis, G., Hunston, S. \& Manning, E. (1996). Grammar Patterns 1: Verbs. London: Harper Collins.

Fredriksson, A. (2016). A Corpus-based Contrastive Study of the Passive and Related Constructions in English and Swedish [Unpublished doctoral dissertation]. University of Gothenburg.

Gustafsson, E. (2014). Variation of English Passives Used by Swedes. A Corpus-based Study of the Usage of Be-passives and Get-passives. Student Thesis, Linnaeus University, Sweden.

Huddleston, R. \& Pullum, G. (2002). The Cambridge Grammar of the English Language. Cambridge: Cambridge University Press.

Leech, G., Hundt, M, Mair, C., and Smith, N. (2009). Chang in contemporary English. A grammatical study. Cambridge: Cambridge University Press.

Loan, N. T. T. (2019). A Case Study of Teacher Feedback on Thai University Students' Essay Writing. GEMA Online ${ }^{\circledR}$ Journal of Language Studies, 19(2), 121-138.

Mair, C. (2006). Tracking Ongoing Grammatical Change and Recent Diversification in Presentday Standard English: The Complementary Role of Small and Large Corpora. In Renouf, A. \& Kehoe, A. (Eds.), The Changing Face of Corpus Linguistics (pp. 355376). Amsterdam: Rodopi.

Mair, C. \& Leech, G. (2006). Current Changes in English Syntax. In Aarts, B. \& McMahon, A. (Eds.), The Handbook of English Linguistics (pp.318-342). Oxford: Blackwell.

McEnery, T. and Xiao, R. (2010). Corpus-based Contrastive Studies of English and Chinese. New York: Routledge.

Quirk, R, Greenbaum S., Leech, G. \& Svartvik, J. (1985). A Comprehensive Grammar of the English Language. London: Longman

Sawasaki, K. (2000). On Adversity in English Get-Passives. Journal of Hokkaido Linguistics. $1,15-28$.

Schwarz, S. (2017). "Like Getting Nibbled to Death by a Duck": Grammaticalization of the Get-passive in the TIME Magazine Corpus. English Word-Wide, 37(3), 305-335. 
Schwarz, S. (2019). Signs of Grammaticalization. Tracking the Get-passive through COHA. In Claridge, S. \& Bo_s, B. (Eds.), Developments in English Historical Morpho-Syntax. (pp. 199-222). Amsterdam: John Benjamins Publishing Company.

Schmitt, N. (2010). Research Vocabulary. A Vocabulary Research Manual. London: Palgrave Macmillan.

Simargool, N. (2008). Interlanguage Passive Construction. Pan-Pacific Association of Applied Linguistics. 12(1), 97-103

Stubbs, M. (2001). Words and Phrases: Corpus Studies of Lexical Semantics. Oxford: Backwell.

Villalibre, E. (2015). Is the Get-passive Really That Adversative? Miscelánea: A Journal of English and American Studies. 51, 13-26.

Wanner, A (2013). The Get-passive at the Intersection of Get and the Passive. In Alexiadou, A. \& Scahfer, F. (Eds.), Non-canonical Passives (pp. 43-62). Amsterdam: John Benjamins Publishing Company.

\begin{abstract}
ABOUT THE AUTHOR
Supakorn Phoocharoensil is Associate Professor of Language Institute of Thammasat University. He is currently teaching various undergraduate courses in English for Specific Purposes, and MA. and Ph.D. courses in English Language Teaching and Applied Linguistics. His areas of research interest include Second Language Acquisition, Corpus Linguistics, and English Collocations.
\end{abstract}

